University of Nebraska - Lincoln

DigitalCommons@University of Nebraska - Lincoln

USDA National Wildlife Research Center - Staff Publications
U.S. Department of Agriculture: Animal and Plant Health Inspection Service

February 2008

\title{
Overwintering Site Selection by Short-Horned Lizards (Phrynosoma hernandesi) in Northeastern Colorado
}

\section{Tom Mathies}

U.S. Department of Agriculture, Animal and Plant Health Inspection Service, Wildlife Services, National Wildlife Research Center

Daniel J. Martin

Colorado Division of Wildlife, Wildlife Research Center

Follow this and additional works at: https://digitalcommons.unl.edu/icwdm_usdanwrc

Part of the Environmental Sciences Commons

Mathies, Tom and Martin, Daniel J., "Overwintering Site Selection by Short-Horned Lizards (Phrynosoma hernandesi) in Northeastern Colorado" (2008). USDA National Wildlife Research Center - Staff Publications. 786.

https://digitalcommons.unl.edu/icwdm_usdanwrc/786

This Article is brought to you for free and open access by the U.S. Department of Agriculture: Animal and Plant Health Inspection Service at DigitalCommons@University of Nebraska - Lincoln. It has been accepted for inclusion in USDA National Wildlife Research Center - Staff Publications by an authorized administrator of DigitalCommons@University of Nebraska - Lincoln. 


\title{
Overwintering Site Selection by Short-Horned Lizards (Phrynosoma hernandesi) in Northeastern Colorado
}

\author{
Tom Mathies ${ }^{1,2,3}$ AND Daniel J. Martin ${ }^{4}$ \\ ${ }^{1}$ U.S. Department of Agriculture, Animal and Plant Health Inspection Service, Wildlife Services, National Wildlife \\ Research Center, 4101 LaPorte Avenue, Fort Collins, Colorado 8052-2154, USA; E-mail: tom.c.mathies@aphis.usda.gov \\ ${ }^{2}$ Department of Fishery and Wildlife Biology, Colorado State University, Fort Collins, Colorado 80532-1620, USA \\ ${ }^{4}$ Colorado Division of Wildlife, Wildlife Research Center, 317 West Prospect Road, Fort Collins, Colorado 80526, \\ USA; E-mail: danny.martin@state.co.us
}

\begin{abstract}
Aвstract.-Radio telemetry was used to track 16 adult Short-Horned Lizards (Phrynosoma hernandesi) to their individual overwintering sites on the Central Plains Experimental Range (CPER) in Weld County, Colorado. Above-ground habitat characteristics of overwintering sites and randomly selected points within the study area were assessed. All individuals entered overwintering between 29 August and 19 September with a mean estimated entrance date of 7 September. Arrival of the first subzero nighttime air temperatures occurred shortly thereafter on 16 September. No lizard left its normal area of use to overwinter, and there was no tendency to aggregate. Lizards did not necessarily overwinter on warmer south-facing slopes; the proportion of overwintering sites oriented southward (0.62) was not different from random. Most lizards $(75 \%)$ selected overwintering sites in the banks of washes that had relatively steep slopes and at specific locations where substrate was relatively bare and penetrable. Overwintering sites also tended to have a greater coverage of Yucca glauca $(0.02 \%)$ than the general study area $(0.01 \%)$. Analyses of historical soil temperature data from the CPER revealed that lizards would have to overwinter at a subsoil depth of about $1 \mathrm{~m}$ to avoid freezing temperatures. Banks that contain suitable hibernation sites that are located within an individual's normal area of use may be the habitat feature most important to successful overwintering.
\end{abstract}

All lizards living at latitudes or altitudes where subzero winter temperatures occur must spend part of the year below ground to survive. At such locations, availability of overwintering sites is presumably an important determinant of local occurrence of a species, its local abundance, and at sufficiently high latitudes, geographical range limit.

Despite the obvious importance of information on overwintering ecology to understanding life histories of many lizard species, there have been few formal studies on subsurface overwintering sites, probably because of the inherent difficulty in finding them. However, the literature contains numerous anecdotal accounts (e.g., Sceloporus occidentalis: Van Denburgh, 1922; Sceloporus undulatus hyacinthinus: McClelan et al., 1943; Cnemidophorus neomexicanus and Cnemidophorus inornatus: Christiansen, 1969), with those for winter aggregations probably being overrepresented (e.g., Holbrookia texana: Ramsey, 1948; Urosaurus ornatus: Worthington and Sabath, 1966; Uta stanburiana: Tinkle, 1967; Cnemidophorus tigris: McCoy, 1974; Urosaurus ornatus: Boykin and Zucker, 1993; Eumeces multivirgatus: Stuart and Painter, 1993). More directed studies have conducted method-

\footnotetext{
${ }^{3}$ Corresponding Author.
}

ical and detailed excavations at sites known to be used by lizards during the active season (Bostic, 1966; Etheridge et al., 1983) or opportunistically used effective, but rather coarse, methods (heavy tractor and scraper combination, Cowles, 1941). Although personal observations, notes, and studies on lizard overwintering sites such as these have collectively provided substantial information and insights, it is at the same time apparent that the approaches used are biased, providing little information on what a representative selection of individuals in a population are doing. Indeed, there have been few studies where an objective was to investigate, in an unbiased way, the overwintering sites that individual lizards in a population selected (Grenot and Heulin, 1988; Rutherford and Gregory, 2003). No studies have yet investigated what lizards select relative to that available.

We investigated the types of overwintering sites Short-Horned Lizards, Phrynosoma hernandesi, selected within available habitat at a site in northeastern Colorado. This cryptic and littlestudied lizard has the most extensive latitudinal range of any member of its genus, ranging from southern Durango, Mexico, to southern Alberta, Canada. It is one of only four North American lizard species inhabiting latitudes higher than $50^{\circ} \mathrm{N}$. The ecology of $P$. hernandesi has been well 
studied only at its northern-most range terminus in Alberta (James et al., 1997), primarily because of its very limited distribution there and its provincial "Blue List" status as a species that may be at risk (Alberta Wildlife Management Division, 1996) and more recently as a species of "special concern" under the Species at Risk Act (Committee on the Status of Endangered Wildlife in Canada, Status Assessments, http://www.cosewic.gc.ca/eng/sct0/ index_e.cfm, 2005).

Given the extreme winter temperatures in southern Alberta, it was hypothesized that $P$. hernandesi overwintered deep within rock crevasses of the formation that underlies much of the lizard's habitat there (G. L. Powell and A. P. Russell, A radio telemetric study of movement, thermal ecology and hibernation site selection in an Alberta population of the eastern ShortHorned Lizard [Phrynosoma douglasii brevirostre], report submitted to Alberta Environmental Protection, Fish and Wildlife Division, Lethbridge, Alberta, Canada, 1994; James et al., 1997). However, radio telemetry studies revealed that individuals overwintered under only about $10 \mathrm{~cm}$ of loose soil on a south-facing slope. At our study site for P. hernandesi in northeastern Colorado, temperatures during winter are also severe, with air temperatures routinely falling below $-10^{\circ} \mathrm{C}$ and the frost line extending to about $1 \mathrm{~m}$ during the coldest months. The main objective of this study was to determine surface feature characteristics of adult $P$. hernandesi overwintering sites and to assess the availability of these sites within their environment. Although the critical features of overwintering sites are presumably subsurface, surface features may govern these features or determine an individual's access to these features.

\section{Materials And Methods}

Study Site Description.-This study was conducted in 2005 on the Central Plains Experimental Range (CPER) in Weld County, Colorado. The CPER is a 6,200-ha research area maintained by the U.S. Department of Agriculture Agricultural Research Service (USDA ARS) for applied rangelands research. The vegetation of the CPER is dominated by shortgrasses $(64 \%)$, forbs $(7 \%)$, succulents $(21 \%)$, and halfshrubs (8\%); the key species of these groups being Bouteloua gracilis and Buchloe dactyloides; Sphaeralcea coccinea; Opuntia polyacantha; and Chrysothamnus nauseosus, Gutierrezia sarothrae, and Eriogonum effusum, respectively (Shortgrass Steppe LTER, http://sgs.cnr.colostate.edu, 2006). The study site was bisected by a large wash (Owl Creek) running north to south that rarely, and only briefly, carries water. To the west, this wash cuts into steep east-facing hills eroded by a number of smaller washes feeding into the main wash. Immediately to the east of the main wash are much lower hills. Vegetation on both sides of the main wash was as described above but with the addition of numerous stands of Yucca glauca.

Climatological Data.-To investigate the air temperatures at which $P$. hernandesi initiated overwintering, daily maximum and minimum air temperatures were obtained for 1 June to 31 December, 2005. To investigate the distance below the soil surface lizards would likely have to overwinter to avoid freezing temperatures, we obtained records of daily minimum soil temperatures for the years, 1972-1979, 19811982, 1984, 1986-1990, and 1992-1994 (years between 1972 and 1994 that had missing data were excluded). Soil temperatures were measured at depths of 2.5, 10.2, 20.3, 50.8, 101.6, and $182.9 \mathrm{~cm}$ below ground. Temperature data were obtained from a weather station maintained by the Shortgrass Steppe Long Term Ecological Research group (SGS LTER) located about $5 \mathrm{~km}$ from our study site. Elevations at the weather station and our study site were $1,652 \mathrm{~m}$ and about 1,660 m, respectively.

Animals and Radio Tracking.-Overwintering sites were located by radio tracking 16 adult lizards, three males and 13 females, to their overwintering sites. These individuals were captured by hand during systematic searches conducted in the morning or late afternoon and on serendipitous encounters. Approximately equal effort was spent searching in the main habitat types on the site. Upon capture, a lizard was weighed to the nearest $0.1 \mathrm{~g}$ using an electronic balance (Model PP-62; Acculab Sales and Marketing, Edgewood, NY). Body masses of adults ranged from 13.0-25.2 g. Radio transmitters (Model 1645; Advanced Telemetry Systems, Isanti, MN) weighed $0.9 \mathrm{~g}$ each. A transmitter was attached to each lizard using a modified method of W. Sherbrooke (pers. comm.): a transmitter was coated ventrally with a small mass of commercial $100 \%$ silicone adhesive, and a thin film was applied to its dorsal side. The transmitter was then firmly pressed down on the back of the lizard just anterior to the pelvic girdle with the transmitter antenna directed posteriorly. Excess adhesive was smoothed out such that all edges of the transmitter were covered and in contact with the lizard's dorsum. To help camouflage the transmitter, it was lightly dusted with a pinch of powdery substrate, and any not adhering to the silicone was blown off. Each lizard was then immediately released at its point of capture, the entire process from time of capture to release 
taking only about $8 \mathrm{~min}$. Disregarding the mass of the glue and affixed substrate, transmitter mass constituted 3.6-6.9\% of lizard body mass $($ mean $=4.7 \pm 3.2 \%)$. No transmitters fell off or set in a position different than the original placement. However, all lizards did shed their skins once and lizards were relocated and transmitters reattached. On the many occasions transmittered lizards were observed, none showed any apparent discomfort from the transmitter and their behavior appeared normal.

Lizards were relocated at least once weekly using a hand-held radio receiver (Model R-100, Communications Specialists, Inc., Orange, CA) with a three-element folding Yagi antenna (AF Antronics, Inc., Urbana, IL). Upon visually sighting a lizard, its location was recorded in Universal Transverse Mercator coordinates (North American Datum of 1983) using a handheld global positioning system (GPS) unit (Model GPSmap 60CS, Garmin International Inc., Olathe, KS). Mean estimated coordinate error was $2.9 \pm 0.35 \mathrm{~m}$. The criteria for determining the location of an overwintering site was $\geq 2$ consecutive locations with essentially identical coordinates (i.e., distance between coordinates less than GPS error estimates) together with no visual sightings of the lizard. Of these two or more sets of coordinates, we considered the date that the first location was taken to be the outer bounding date the lizard entered into its overwintering site; the inner bounding date was the date from the previous location on which the lizard was visually sighted and active. For each lizard, we estimated its date of entry into overwintering as the midpoint (median date) between the inner and outer bounding dates. The radio receiver (without antenna) was used at close range to estimate the location of each lizard, and locations were marked with flagging tape. Lizards were not excavated to avoid possibly compromising their ability to overwinter successfully.

Random Sampling of Habitat.-To determine the extent to which lizards selected particular sites for overwintering, we compared surface features of sites selected by lizards to those available. To assess features available to lizards, we used the Animal Movement extension (vers. 2.0, P. N. Hooge and B. Eichenlaub, Alaska Science Center-Biological Science Office, USGS, Anchorage, 2001) for ArcView (vers. 3.2, ESRI, Redlands, CA) Geographical Information System to delineate the study area. All locations (including locations prior to entering hibernation, $N=347$ ) of individuals tracked to an overwintering site were used to create a Minimum Convex Polygon to which was added a surrounding $50 \mathrm{~m}$ wide buffer delineating the study area. The $50 \mathrm{~m}$ buffer was included because we assume the transmittered lizards occasionally traveled beyond the areas in which they were observed. We then generated 32 sets of randomly located coordinates within the combined area of the polygon and buffer, none closer than $1 \mathrm{~m}$ apart. No random points were coincident with locations of lizard overwintering sites. The 32 randomly located points were uploaded into a GPS, which was then used to physically navigate to each point.

Overwintering Site and General Habitat Characteristics.-We assigned each lizard-centered and randomly located point to one of the three broad habitat types: wash bottom, bank of wash, or upland. At each point, ocular estimates of vegetative cover and substrate type (exposed) were made within a $1-\mathrm{m}^{2}$ Daubenmire frame. For overwintering sites, the frame was centered on the estimated below-ground position of the lizard. For randomly located points, the frame was tossed on the ground at the location of the point. The Daubenmire cover class method (Daubenmire, 1959) was used assign the following vegetation and substrate cover classes (CC): CC1 (5\% or less), CC2 (6-25\%), CC3 (26-50\%), CC4 $(51-75 \%)$, CC5 (76-95\%), and CC6 (96\% or greater). The vegetation and substrate features we measured were inclusive of the major types on the study site. These features were "bare soil" ( $<1 \mathrm{~cm}$ grain size), "grass" (primarily Bouteloua gracilis), and "yucca." Other cover features such as forbs, woody shrubs, stones, and "cow patties" (domestic bovine excrement) were common on the study site but not included in the analyses because the mean CC values of these features for both lizard-centered and random points were $<5-25 \%$ (i.e., CC2). At each point, aspect in relation to true north and slope were measured with an inclinometer (Model 515, Silva Sweden AB, Sollentuna, Sweden) placed on a $33.5 \times 26.5 \mathrm{~cm}$ board placed on the approximate center of each plot. Aspect values were grouped into quadrants delineated by the four cardinal directions. Soil penetrability $\left(\mathrm{kg} / \mathrm{cm}^{2}\right)$ was measured using a Pocket Penetrometer (Forestry Suppliers, Inc., Jackson, MS). Four measurements of soil penetrability were taken at each point, one measurement within each of the four quadrants of the Daubenmire frame. The precise location of each measurement within a quadrant was always at what appeared to be the loosest soil available to a lizard for burrowing. For each lizard-centered and random point, we calculated the mean soil penetrability value, and these individual means were used in the analyses. Larger values indicate less penetrable soil.

Statistical Analyses.-Incidence of overwintering sites with respect to broad habitat type was 
assessed using Chi-square tests. Statistical analyses of vegetation and substrate features were based on the midpoint cover class values (e.g., CC3: $37.5 \%$ ). Shapiro-Wilkes tests were used to determine whether these variables were normally distributed. Where appropriate, data were transformed using the $\log _{10}$ transformation. Differences between means of features of overwintering sites and those of the random sample points were initially evaluated using two-factor ANOVA with broad habitat type and site type (overwintering site or random site) as factors. Because sample sizes of overwintering sites in some broad habitat types were small (see Results), differences between site types were, in some cases, examined further by pooling observations across broad habitat type, and then conducting a two-tailed $t$-test. Aspect of overwintering sites was assessed using a Chisquare goodness-of-fit test with the null hypothesis that the proportions of sites in each of the quadrants delineated by the four cardinal directions were equal. Shapiro-Wilkes tests were conducted using SAS ${ }^{\circledR}$ statistical software (vers. 9.1, 2002-2003, SAS Institute Inc., Cary, NC). All other analyses were conducted using StatView ${ }^{\circledR}$ statistical software (vers. 5.0.1, 1999, SAS Institute Inc., Cary, NC). Means are reported \pm 1 SD. Statistical significance was assessed at $P<0.05$.

\section{RESULTS}

Lizards entered overwintering between 29 August and 19 September 2005 with mean and median entrance dates of 7 and 4 September, respectively. One individual was observed apparently in the process of submergence. This individual was radio located partially buried in loose sand one week; the following week the radio signal for that lizard indicated it had not changed location, but the lizard was no longer visible. Subsequent confirmations of no location change indicated the lizard was below-ground at that location for the season. We mention this account because it was apparent that this lizard did not use an animal burrow. For other lizards, we could not rule out the possibility that they might have used existing burrows (open or collapsed) because these were sometimes present within $1 \mathrm{~m}$ of overwintering sites and lizards could have used these to burrow laterally to reach their final resting positions.

Spatial locations of lizard overwintering sites and randomly located sampling points are shown in Figure 1. No lizard left its individual area of use to overwinter (data on movements and individual home ranges to be presented elsewhere). Representative overwintering sites in each of the three broad habitat types are

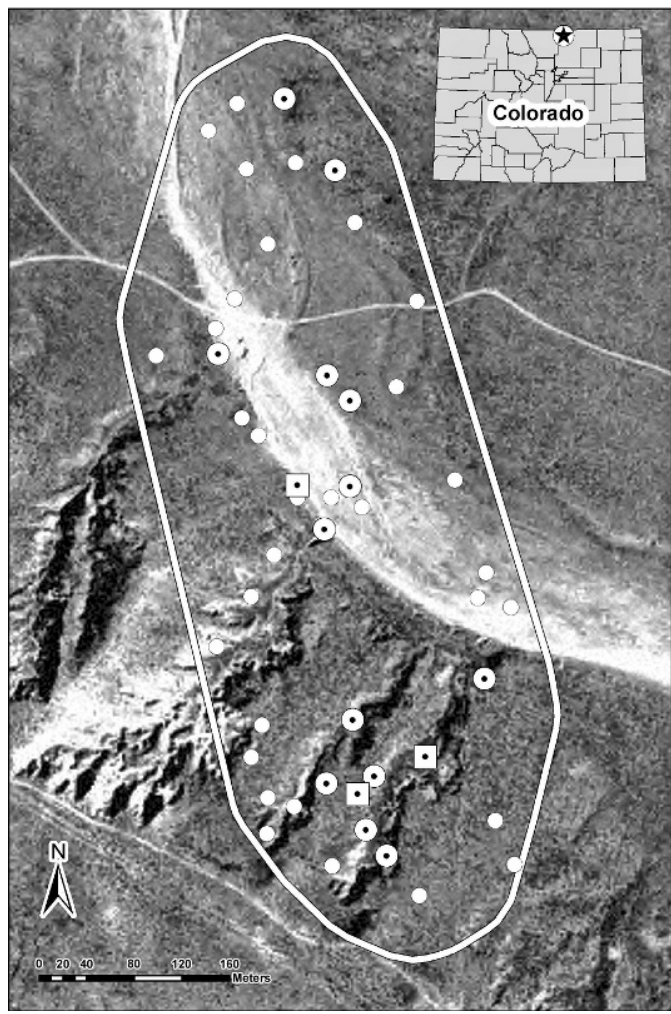

FIG. 1. Spatial locations of overwintering sites of 16 adult Phrynosoma hernandesi on the Central Plains Experimental Range, Weld County, Colorado. Study site is bisected north to southeast by a large dry wash. Point-centered squares and circles indicate overwintering site locations of males $(N=3)$ and females $(N=$ 13), respectively. Open circles indicate locations of randomly sampled points (see Materials and Methods). The star on the map inset shows the location of the study site in Colorado.

shown in Figure 2. The proportion of overwintering sites located in the bank of the main wash or the banks of feeder washes was 0.75 , whereas the proportion of randomly located points occurring on banks was 0.09. The proportions of overwintering sites located in the wash bottom and on upland were both 0.12 , whereas the proportion of randomly located points occurring in these two habitat types were 0.44 and 0.47 , respectively. An initial Chi-square test indicated that there was at least one significant difference in proportions $\left(\chi^{2}{ }_{3}=\right.$ $21.34, P<0.0001)$. Partitioning the contingency table by removing the category with the greatest $\chi^{2}$-value (upland) still resulted in a significant difference in proportions $\chi_{1}^{2}=14.24, P=$ 0.0002 . Thus, most horned lizards $(N=12)$ selected overwintering sites within banks, which were comparatively scarce, although two lizards overwintered in each of the two 

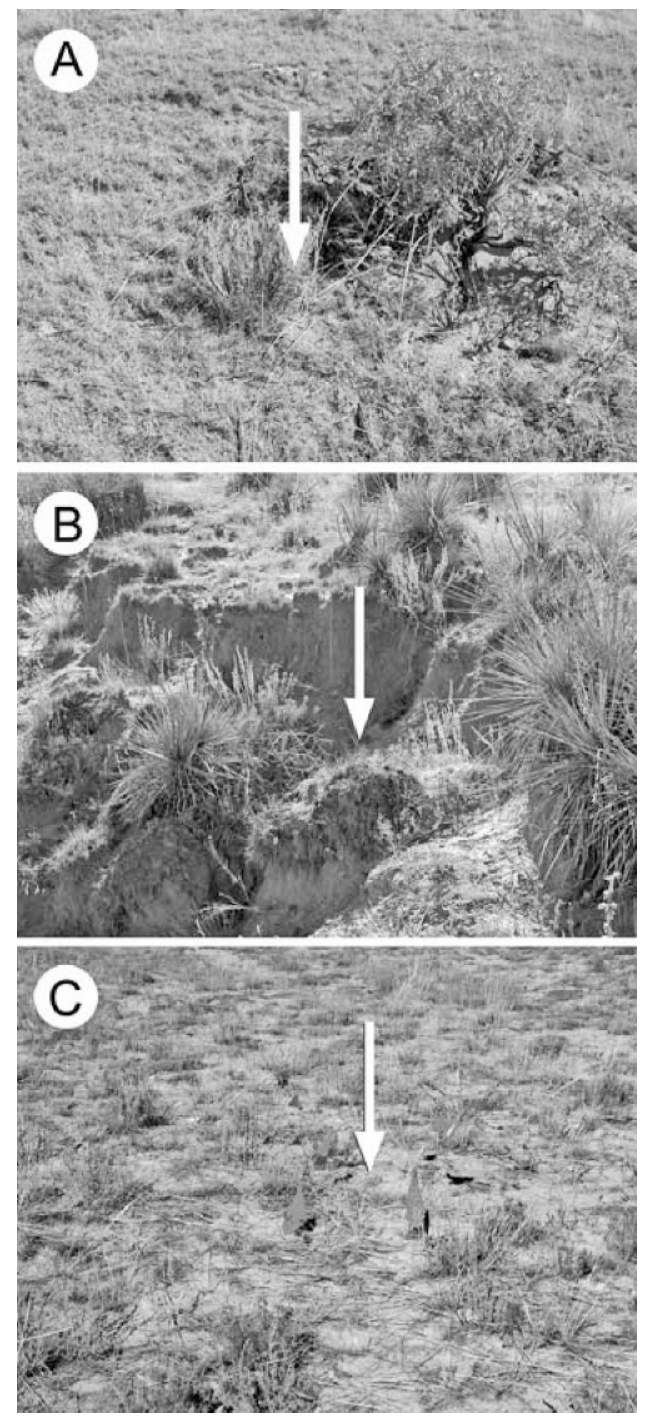

FIG. 2. Overwintering sites of three adult Phrynosoma hernandesi on the Central Plains Experimental Range, Weld County, Colorado. Each panel is representative of one of the three broad habitat types on the study site. Arrows point to the approximate belowground positions of overwintering lizards. (A) Female: upland habitat type; southwest-facing grassy hillside. (B) Female: wash bank habitat type; southeast-facing eroding wash bank; clumps of Yucca glauca present. This was the broad habitat type selected by most lizards for overwintering (see Results). (C) Female: wash bottom habitat type; southeast-facing wash bottom.

other broad habitat types, which were about equally common.

Mean slope differed among broad habitat types $\left(F_{2,42}=5.66, P=0.007\right)$, but significance mainly was caused by differences among random sites rather than overwintering sites.
Thus, even though most lizards overwintered in banks, and banks tended to have the steepest slopes, the few lizards that overwintered in the flatter broad habitat types also chose microsites with relatively steep slopes. The overall ANOVA did not reveal a difference in mean slope between overwintering sites and random sites $\left(F_{1,42}=1.82, P=0.18\right)$. However, when data were pooled across broad habitat type for each site type, mean slope of overwintering sites $\left(20.5 \pm 12.0^{\circ}\right)$ and that of random sites $(8.0 \pm$ $\left.7.8^{\circ}\right)$ differed $\left(t_{46}=4.00, P=0.0002\right)$. Mean soil penetrability did not differ among broad habitat types $\left(F_{2,42}=0.18, P=0.83\right)$ but differed between site type (Fig. $3 \mathrm{~A} ; F_{1,42}=7.08, P=$ 0.01 ). Mean penetrabilities for overwintering sites were lower than those for random sites in all three broad habitat types, but sample sizes were too small in some broad habitat types to permit meaningful application of post hoc means separation procedures (recall lower values indicate greater penetrability). Mean soil penetrabilities of overwintering sites and random sites were $0.15 \pm 0.20 \mathrm{~kg} / \mathrm{cm}^{2}$ and $0.45 \pm$ $0.52 \mathrm{~kg} / \mathrm{cm}^{2}$, respectively (data pooled across broad habitat types for each site type). Mean percent bare soil did not differ among broad habitat types $\left(F_{2,42}=3.36, P=0.05\right)$, between site type $\left(F_{1,42}=0.02, P=0.90\right)$, or when data were pooled across broad habitat types $\left(t_{46}=\right.$ $0.85, P=0.41)$. Mean percent bare soil for overwintering sites and random sites were $3.4 \pm$ 1.26 and $3.0 \pm 1.22 \%$, respectively. Mean percent grass coverage differed among broad habitat types (Fig. 3B; $F_{2,42}=4.28, P=0.02$ ) but not between site types $\left(F_{1,42}=3.50, P=0.07\right)$. Statistical significance among broad habitat types mainly was caused by differences among random sites (one factor ANOVA; $F_{2,29}=4.11, P$ $=0.03$ ) rather than among overwintering sites (one factor ANOVA; $F_{2,15}=1.58, P=0.24$ ). However, when data were pooled across broad habitat types, mean percent grass cover at overwintering sites $(1.94 \pm 0.85 \%)$ and random sites $(3.12 \pm 1.18 \%)$ differed $\left(t_{46}=3.42, P=\right.$ $0.001)$. Mean percent yucca coverage differed among broad habitat type (Fig. 3C; $F_{2,42}=4.16$, $P=0.02)$ but not between site types $\left(F_{1,42}=\right.$ $0.27, P=0.60$ ). Inspection of Figure $3 \mathrm{C}$ indicates significance among broad habitat types mainly was caused by most lizards choosing overwintering sites on banks with relatively high yucca coverage. Pooling data across broad habitat types confirmed this; mean percent yucca coverage of overwintering sites $(2.00 \pm$ $1.21 \%)$ and random sites $(1.19 \pm 0.40 \%)$ differed $\left(t_{46}=3.39, P=0.001\right)$. Proportions of overwintering site aspects within the quadrants delineated by the four cardinal directions did not differ $\left(\chi^{2}{ }_{3}=3.5, P=0.32\right)$. 

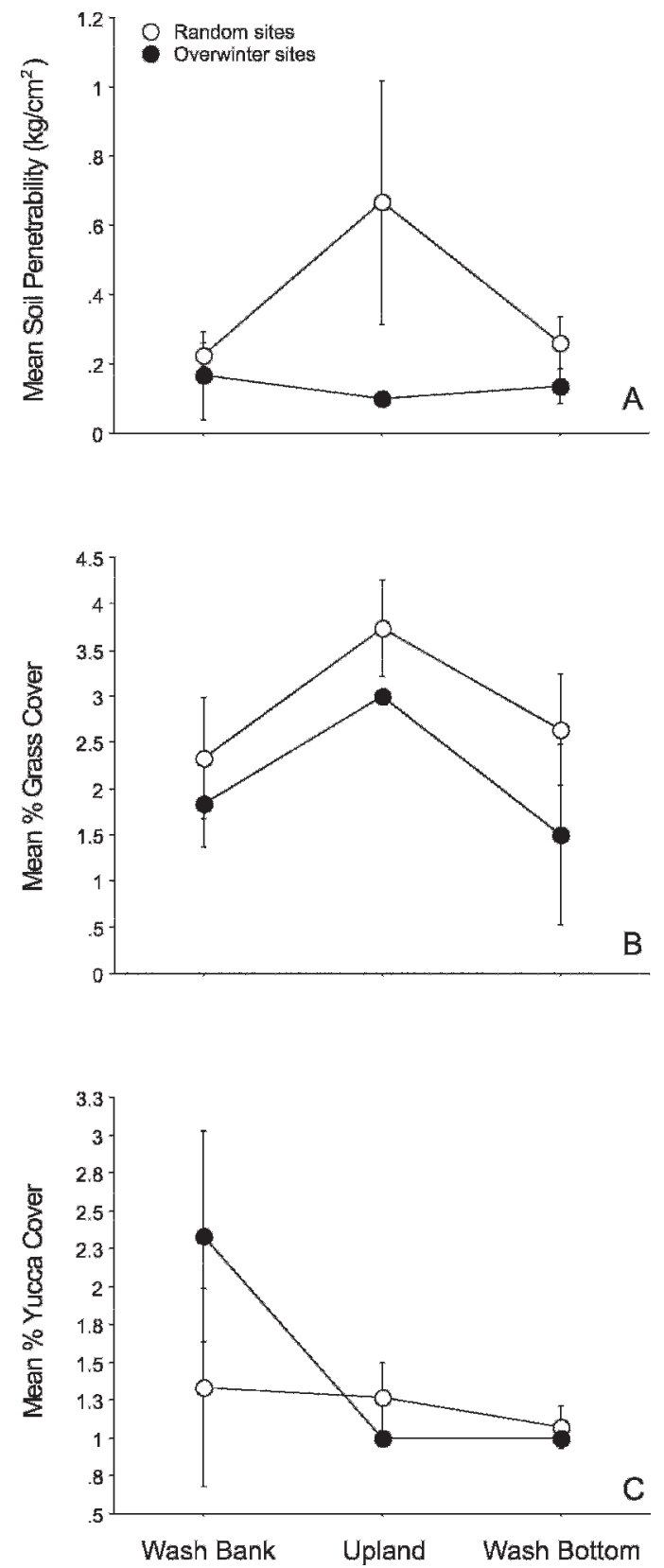

FIG. 3. Means with $95 \%$ confidence intervals for habitat characteristics of overwintering sites of adult Phrynosoma hernandesi (filled circles) and randomly selected sites (open circles).

Daily minimum and maximum air temperatures from 1 June to 31 December 2005 are shown in Figure 4. On average, lizards entered into overwintering 10 days before the arrival of the first subzero nighttime air temperatures (16 September, followed by two additional consecutive nights of subzero temperatures). Figure 5

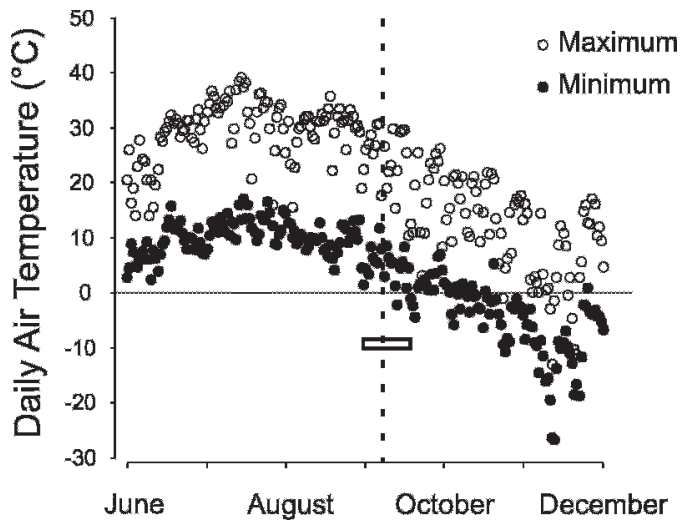

FIG. 4. Scatter plots of maximum (open circles) and minimum (filled circles) air temperatures measured at Central Plains Experimental Range, Weld County, Colorado. Horizontal bar and vertical dashed line indicate the range of dates and mean date lizards entered into overwintering, respectively.

shows estimated minimum temperatures lizards would experience depending on their subsoil depth. Based on these data, lizards would have to overwinter at soil depths greater than $1 \mathrm{~m}$ to avoid freezing temperatures. The relationship between temperature and soil depth was curvilinear, meaning that overwintering a few centimeters below ground sharply reduces the severity of the subzero temperatures experienced, but overwintering deeper provides increasingly less protection per unit distance burrowed. Similarly, overwintering a few centimeters below ground sharply reduces the number of days spent at subzero soil temperatures, but each increment of depth below the surface yields an increasingly smaller reduction in the number of days spent below freezing (Fig. 6).

\section{Discussion}

All $P$. hernandesi in this study entered into overwintering over a 22-day period in late August to early September, just prior to the arrival of the first subzero nighttime air temperatures. Daytime air temperatures at this time were as high as those when adults would have been active in late spring. Insect prey were noticeably fewer at this time, but ants, a main food item of $P$. hernandesi on our study site, were still active above-ground (pers. obs.). Thus, it is tempting to speculate that the cue for winter submergence is the onset of freezing nighttime air temperatures rather than unfavorable daytime temperatures or declining availability of food. However, young P. hernandesi born that year were still active for up to two weeks after all the adults had entered into 
overwintering (unpubl. data). Later submergence of juveniles has been noted in more southern parts of the specie's range (Degenhardt et al., 1996), and later submergence of juveniles seems to be a general phenomenon among North American lizard species (Smith, 1946). Thus, freezing nighttime air temperatures as the cue for winter submergence of adult $P$. hernandesi would require further investigation.

Casual inspection of the locations of overwintering $P$. hernandesi (Fig. 1) shows there was no tendency to aggregate, as has been observed in some lizard species (McCoy, 1974; Worthington and Sabath, 1966), and no lizard left its normal area of use to select an overwintering site. These observations are the most compelling evidence that overwintering sites were not limited on the study site. Many squamates are known to move substantial distances to communal hibernacula, particularly at high latitudes (e.g., Brown and Parker, 1976), but individual $P$. hernandesi simply select suitable sites within their normal individual areas of use. Therefore, winter submergence and spring emergence are events unlikely to be easily observed, and it is probably for this reason that overwintering sites of this species have not been previously reported.

A potentially important finding was that $P$. hernandesi often overwinter in the steep sides of wash banks. Although banks have areas of soft sand that would be easy for a lizard to burrow into, soil penetrabilities of random sites did not differ among broad habitat types. Thus, banks are selected for other reasons. One possible reason is that lizards may be better able to dig into banks than into flatter substrates because of the steeper angle presented to the lizard. Another consideration is that banks have relatively good drainage and that such sites would, therefore, remain relatively dry. Selection of relatively dry overwintering sites may be important for two reasons: for reducing moisture-related health problems that may arise during the long overwintering period; and to facilitate supercooling, a potential that would be enhanced in dry sites because there would be fewer environmental ice crystals contacting the integument of the lizard. In animals that are supercooled, such crystals have potential to induce internal ice nucleating points and, thereby, freezing of tissues (Costanzo et al., 1995).

Phrynosoma hernandesi did not seek out relatively open areas for overwintering, because there was no difference between the mean percent bare soil of overwintering sites and random sites. However, they did select sites with less grass cover. The dominant grass species on the study site is $B$. gracilis, a wiry short grass species that $P$. hernandesi negotiates through particularly cumbersomely, and it has a densely interwoven network of tough rhizomes and roots that would be difficult for a lizard to dig through. An interesting, but inexplicable, finding was that $P$. hernandesi selected overwintering sites with a relatively high coverage of $Y$. glauca. Like a number of other Yucca species at high latitudes, Y. glauca forms dense, impenetrable clumps, and it is possible these clumps offer some additional thermal or other protection to overwintering lizards. Another possibility is that accumulation of dead vegetative litter beneath yucca clumps amends the soil, increasing its penetrability.

Given the severity of winter temperatures at our study site, it might be expected that lizards would choose overwintering sites with warmer southern aspects. Hibernacula selection has been relatively well studied in snakes, and those at high latitudes often have a southerly aspect (e.g., Carpenter 1953; Prior and Weatherhead 1996; Andersson, 2003). Although most overwintering sites were oriented to the southeast, the proportions within each of the four compass quadrants did not differ.

Although we have no information on how deep $P$. hernandesi overwinter below ground, historical data on minimum subsoil temperatures show that the frost line at our study site can extend as far as $1 \mathrm{~m}$ below the surface, although only for an average of four days. Overwintering at lesser depths results in exposure to proportionately colder temperatures and proportionately longer durations at those temperatures. It is possible that adult $P$. hernandesi generally overwinter below the frost line. Depths such as this and greater have been reported for other North American lizards: Eumeces fasciatus has been found at a depth of eight feet in Kansas, and 52 Eumeces septentrionalis were found at a depth of $4.5 \mathrm{ft}$ below ground in Iowa (Smith, 1946). However, the slim body plans of skinks might better enable these taxa to gain deeper subsoil access than Phrynosoma. Further, it seems improbable that neonate $P$. hernandesi, which are born in late summer and attain an average SVL of only $36 \mathrm{~mm}$ by October (T. Mathies and D. J. Martin, unpubl. data), are able to reach such depths. G. L. Powell and A. P. Russell (A radio telemetric study of movement, thermal ecology and hibernation site selection in an Alberta population of the eastern Short-Horned Lizard [Phrynosoma douglasii brevirostre], report submitted to Alberta Environmental Protection, Fish and Wildlife Division, Lethbridge, Alberta, Canada, 1994) reported that adult $P$. hernandesi at a limital site in Alberta, Canada, overwintered under only about $10 \mathrm{~cm}$ of loose soil but on a south- 


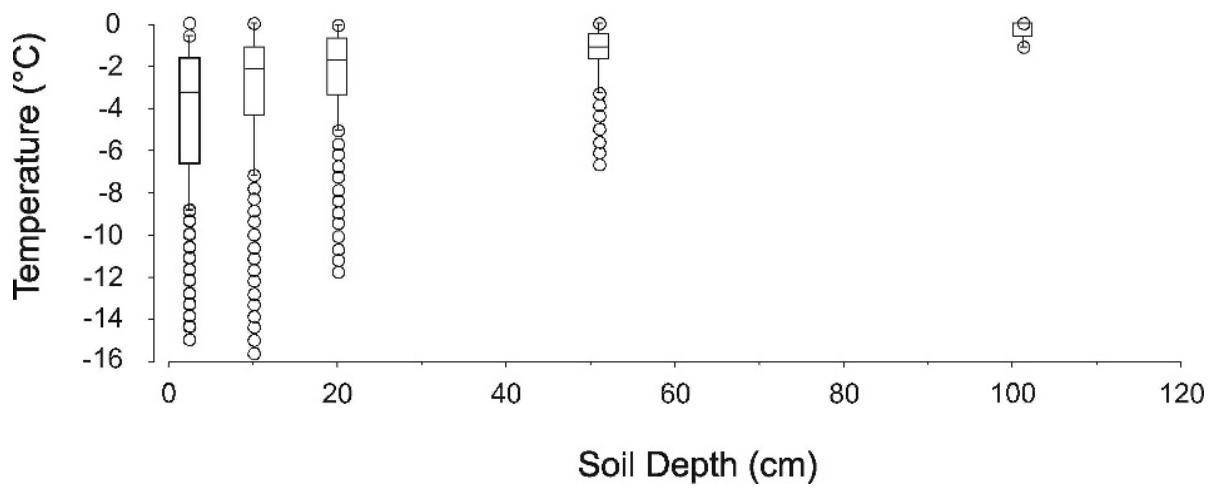

FIG. 5. Box plot of soil temperatures of $\leq 0^{\circ} \mathrm{C}$ measured at five soil depths at the Central Plains Experimental Range, Weld County, Colorado.

facing slope. At this depth at our study site, minimum median soil temperatures would have been about $-2^{\circ} \mathrm{C}$, ranged as low as $-15^{\circ} \mathrm{C}$ (Fig. 5), and the number of days at or below $0^{\circ} \mathrm{C}$ would have been about 114 days (Fig. 6). These findings raise the possibility that $P$. hernandesi has the physiological capacity to withstand freezing body temperatures. Lowe et al. (1971) found that all the phrynosomatid lizards they tested (16 species, including tropical species; no Phrynosoma) could be supercooled to at least $-5^{\circ} \mathrm{C}$ but stressed that this phenomenon was attributable to nothing more than the intrinsic supercooling properties of water. However, research on the cold hardiness of the Palaearctic lacertid, Lacerta vivipara has shown this species can be supercooled to $-3.5^{\circ} \mathrm{C}$ for at least three weeks, and it tolerates freezing of its tissues to as low as $-3.0^{\circ} \mathrm{C}$ for up to three days (Costanzo et al., 1995). Thus, laboratory and field studies on the cold hardiness of $P$. hernandesi might reveal further insights into the physiology of cold hardiness in vertebrates, and the extensive latitudinal range of $P$. hernandesi could offer an excellent system to examine latitudinal variation. However, a more immediate follow-up study to the present work would be to directly examine the physical characteristics and microclimates of the below-ground sites selected by $P$. hernandesi relative to those available.

Our observations reveal at least one feature of habitat use by $P$. hernandesi that may be useful for making management decisions for this species. Their propensity to select overwintering sites within wash banks suggests availability of this habitat may be important to the persistence of populations, at least in our area. Two other populations we know of in northeastern Colorado also occur along washes with eroding banks with a similar geology and topology to that in the present study. Further studies directly examining the physical characteristics and microclimates of overwintering sites within wash banks versus those in other habitat types are needed.

Acknowledgments.-This study was supported by a Colorado Wildlife Conservation Grant to the authors and conducted under Colorado Division of Wildlife (CDOW) Scientific Collection Permit number 05-HP927. The CDOW Animal Care and Use Committee approved all procedures involving lizards. Air and soil temperature data were graciously provided by the SGS LTER, a partnership between Colorado State University, USDA ARS, and the U.S. Forest Service Pawnee National Grassland. The National Science Foundation Long-Term Ecological Research program (NSF grant DEB0217631) provided significant funding for these data. M. Lindquist (SGS LTER) provided the information enabling us to select the study site. M. Ashby (USDA ARS) and T. Jackson (CDOW) provided assistance obtaining study permits. L.

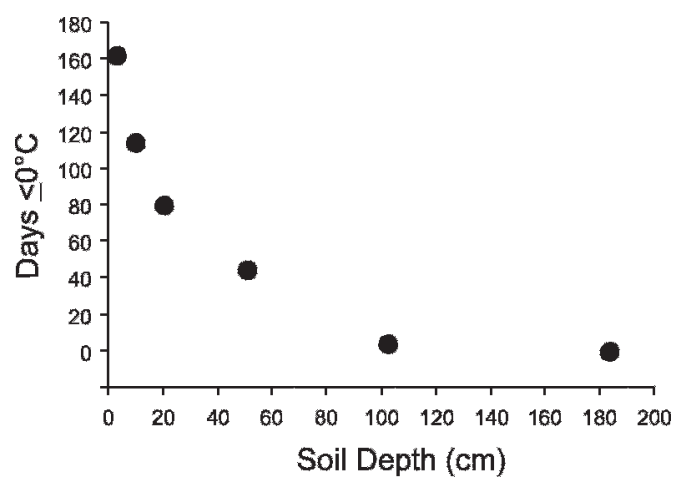

FIG. 6. Number of days (means) where soil temperature was $\leq 0^{\circ} \mathrm{C}$ with respect to soil depth at the Central Plains Experimental Range, Weld County, Colorado. 
Wolfe (CDOW) provided input on the method for transmitter attachment. B. Ross, J. Campbell, and L. Rosen provided assistance in the field.

\section{Literature Cited}

Alberta Wildlife Management Division. 1996. The Status of Alberta Wildlife. Alberta Natural Resources Service, Edmonton, AB, Canada.

ANDERSSON, S. 2003. Hibernation, habitat and seasonal activity in the adder, Vipera berus, north of the Arctic Circle in Sweden. Amphibia-Reptilia 24: 449-457.

Bostic, D. L. 1966. Thermoregulation and hibernation of the lizard Cnemidophorus hyperythrus beldingi (Sauria, Teiidae). Southwestern Naturalist 11: 275-289.

BOYKIN, K., AND N. ZuCKer. 1993. Winter aggregation on a small rock cluster by the tree lizard Urosaurus ornatus. Southwest Naturalist 38:304-306.

Brown, W. S., AND W. S. PARKer. 1976. Movement ecology of Coluber constrictor near communal hibernacula. Copeia 1976:225-242.

CARPenter, C. 1953. A study of hibernacula and hibernating associations of snakes and amphibians in Michigan. Ecology 34:74-80.

Christiansen, J. L. 1969. Notes on hibernation of Cnemidophorus neomexicanus and C. inornatus (Sauria: Teiidae). Journal of Herpetology 3:99-100.

Costanzo, J. P., C. Grenot, and R. E. Lee. 1995. Supercooling, ice nucleation and freeze tolerance in the European common lizard, Lacerta vivipara. Journal of Comparative Physiology B 165:238-244.

Cowles, R. B. 1941. Observations on the winter activities of desert reptiles. Ecology 22:125-140.

Daubenmire, R. F. 1959. Canopy coverage method of vegetation analysis. Northwest Science 33:43-64.

Degenhardt, W. G., C. W. Painter, and A. H. Price. 1996. Amphibians and Reptiles of New Mexico. University of New Mexico Press, Albuquerque.

Etheridge, K., L. C. Wit, and J. C. Sellers. 1983. Hibernation in the lizard Cnemidophorus sexlineatus (Lacertila: Teiidae). Copeia 1983:206-214.

Grenot, C., and B. Heulin. 1988. Emploi de radioisotopes pour la localization de Lacerta vivipara et l'étude de son métabolisme au cours de l'hivernage. Comptes rendus de l'Académie des sciences. Série III 307:305-310.
James, J. D., A. P. Russell, And G. L. Powell. 1997. Status of the Eastern Short-Horned Lizard (Phrynosoma douglassii brevirostre) in Alberta. Alberta Environmental Protection. Wildlife Management Division, Wildlife Status Report no. 5, Edmonton, AB, Canada.

Lowe, C. H., P. J. Lardner, and E. A. Halpern. 1971. Supercooling in reptiles and other vertebrates. Comparative Biochemistry and Physiology 39A:125-135.

McClellan, W. H., R. J. Mansueti, and F. Groves. 1943. The lizards of central and southern Maryland. Natural History Society of Maryland Proceedings $8: 1-42$.

McCoy, C. J. 1974. Communal hibernation of the lizard Cnemidophorus tigris (Teiidae) in Colorado. Southwestern Naturalist 19:218.

Prior, K. A., AND P. J. Weatherhead. 1996. Habitat features of Black Rat Snake hibernacula in Ontario. Journal of Herpetology 30:211-218.

RAMSEY, L. W. 1948. Hibernation of Holbrookia texana. Herpetologica 12:239-240.

Rutherford, P. L., And P. T. Gregory. 2003. How age, sex, and reproductive condition affect retreat-site selection and emergence patterns in a temperatezone lizard, Elgaria coerulea. Ecoscience 10:24-32.

Sмiтh, H. M. 1946. Handbook of Lizards. Cornell University Press, Ithaca, NY.

Stuart, J. N., and C. W. Painter. 1993. Notes on hibernation of the Smooth Green Snake Opheodrys vernalis, in New Mexico. Bulletin of Maryland Herpetological Society 29:140-142.

Tinkle, D. W. 1967. The life and demography of the Side-Blotched Lizard, Uta stansburiana. Miscellaneous Publications of the Museum of Zoology, University of Michigan 132:1-182.

VAn DenburGH, J. 1922. The Reptiles of Western North America: An Account of the Species Known to Inhabit California and Oregon, Washington, Idaho, Utah, Nevada, Arizona, British Columbia, Sonora and Lower California. California Academy of Sciences, San Fransisco.

Worthington, R. D., And M. D. Sabath. 1966. Winter aggregations of the lizard Urosaurus ornatus ornatus (Baird and Girard) in Texas. Herpetologica 22:94.

Accepted: 26 September 2007. 